REVIEWS

\title{
Hsp90 molecular chaperone: structure, functions and participation in cardio-vascular pathologies
}

\author{
I. V. Kroupskaya
}

Institute of molecular biology and genetics NAS of Ukraine 150, Zabolotnogo Str, Kyiv Ukraine, 03680

i.v.kroupskaya@imbg.org.ua

\begin{abstract}
The review is devoted to the analysis of structural and functional properties of molecular chaperon Hsp 90. Hsp90 is a representative of highly widespread family of heat shock proteins. The protein is found in eubacteria and all branches of eukarya, but it is appa-rently absent in archaea. It is one of key regulators of numerous signalling pathways, cell growth and development, apoptosis, induction of autoimmunity, and progression of heart failure. The full functional activity of Hsp90 shows up in a complex with other molecular chaperones and co-chaperones. Molecular interactions between chaperones, different signalling proteins and protein-partners are highly crucial for the normal functioning of signalling pathways and their destruction causes an alteration in the cell physiology up to its death.
\end{abstract}

Keywords: Hsp90, domain, cristal structure, signalling path-ways, apoptosis.

Introduction. When various physical and chemical factors affect the cells, their most frequent target are proteins; they damage the proteins structure and change their functions. In order to cope with protein damage the cells should activate a mechanism of specific defence. The investigation on the processes of cell functioning and folding of proteins in vivo revealed a series of cell components, involved either in the catalysis of protein folding or in the regulation of distribution of newly synthesized proteins among alternative pathways of folding and aggregation [1].
Ellis [2] formulated an assumption that though protein folding is a spontaneous process there are critical stages, at which the participation of cell factors may be crucial. The role of these factors, called molecular chaperones, consists in providing optimal conditions for the process of protein folding via removal of "hindrances" or "inadequate contacts", which results in prevention of non-specific aggregation of proteins, synthesized anew, and providing a transport of these proteins to those intracellular compartments, where they are usually localized and function. The fact that chaperones act as traffic controllers is also supple- 
mented by their participation in penetration of proteins through membranes.

Chaperones are a part of a large family of heat shock proteins (hsp), the synthesis of which in the cell is considerably increased in response to heat shock or other kinds of cell stress. At the same time most proteins of this family are synthesized rather intensively even at normal conditions [1].

Molecular chaperon Hsp90 belongs to a widely spread family of heat shock proteins; they were found in eubacteria and all branches of eukarya, but they are apparently absent in archaea [3]. Hsp90 is one of molecular chaperones, which is abundantly present in the cell at normal conditions. Bacterial chaperone is known as HtpG. A human cell contains four isoforms of chaperones: cytoplasmic form Hsp90 $\beta$, synthesized constitutively in the cells, and inducible form Hsp90 $\alpha$; Hsp90 analogue - GRP94, the expression of which is regulated by glucose - was found in endoplasmic reticulum; and mitochondrial TRAP1/hsp75 [3]. Forms Hsp90 $\alpha$ and $\beta$ are $85 \%$ identical in their amino acid content which may be explained by duplication of genes more than 300 million years ago. There is a high homology among Hsp90 of lower eukaryotes, humans, and prokaryotes: the identity of Hsp 82 of yeast to human Hsp90 $\alpha$ and HtpG is $60 \%$ and $34 \%$, respectively [4].

Hsp90 structure. The crystal structure of a full-length protein Hsp90 was described about 10 years ago [4]. At the same time qualitative crystals of a full-sized protein Hsp90, suitable for X-ray structural analysis, are yet to be studied, there are crystals of specific domains. Hsp90 protein is a dimer of two identical subunits. Each monomer has three independent domains: from highly conservative $\approx 25 \mathrm{kDa}$ $\mathrm{N}$-terminal domain; $\approx 40 \mathrm{kDa} \mathrm{M}$-domain, and $\approx 12$ $\mathrm{kDa}$ C-terminal domain [5] (Fig. 1). N-terminal domain is connected to $\mathrm{M}$ - and $\mathrm{C}$-region via so called charged linker which is variable by both its content and length in different types and isoforms of the protein. The charged linker is not essential for Hsp90 function and is entirely absent in Hsp75/TRAP1 and HtpG [6].

N-terminal domain. The firs significant progress in the study on Hsp90 structure was the determination of $\mathrm{N}$-terminal domain by limited proteolysis [5]. The investigation of the domain crystal structure of human and yeast Hsp90 revealed that it has a two-layer $\alpha \beta$-sandwich structure [7] with a densely folded anti-parallel $\beta$-layer, consisting of eight stripes, closed by nine $\alpha$-coils on one side. There is a deep pocket, formed by ATP/ADP-binding site, in the centre of $\alpha$-coil part. This pocket in N-domain of human Hsp90 was revealed to be an obligatory site of binding geldanamycin (GA) which prevents Hsp9 forming complexes with protein kinase and steroid hormone receptors [8]. The true function of $\mathrm{N}$-domain and its pocket became evident only by the comparison of amino acid sequence of Hsp90 and two ATP-dependent proteins - topoisomerase II (DNA gyrase B, GyrB) and protein MutL. Conservative amino acid residues, involved in ATP binding and its hydrolysis, were defined [9]. The identification of key residues in $\mathrm{N}$-terminal structure of Hsp90 by the method of mutagenesis revealed that $\mathrm{N}$-terminal domain contains ATP-binding site (Fig. 2, a) [5, 6]. Subsequently, crystal structures have been determined for N-terminal domains of the mammalian endoplasmic reticulum Hsp90 isoform GRP94 [10] and HtpG for Escherichia coli $[11]$.

M-domain. After the structural analysis of N-terminal domain of human and yeast Hsp90, the crystal structure of proteolytically resistant, so called middle segment - M-domain of yeast was investigated [12]. Its structure consists of a large $\alpha \beta \alpha$-sandwich fixed to $\mathrm{N}$-terminal site of the protein, and a small $\alpha \beta \alpha$-sandwich, bound to C-terminal domain of Hsp90. $\alpha \beta \alpha$-sandwiches are connected to each other via a solid ring of $\alpha$-coil (Fig. 2, $b$ ). A bigger $\alpha \beta \alpha$-sandwich has a fold (curve) similar to the equivalent region of GyrB and protein MutL, although there is a considerable difference in the region involved in the interaction of MutL and GyrB with DNA. A smaller $\alpha \beta \alpha$-domain is unique, though it has architectural similarity to the bigger, classic $\alpha \beta \alpha$-domain. The analogy between MutL and GyrB was studied using site-specific mutagenesis [9].

It was revealed that the middle segment contains a major site of interaction with "client" proteins. This is a small conservative hydrophobic site with a $\operatorname{Trp}_{300}$ as the centre and an unusual amphipatic protuberance, formed by amino acid residues 327-340. The central 
$\beta$-sheet of $\alpha \beta \alpha$-domain contains a lysin, interacting with $\gamma$-phosphate of ATP, bound to N-domain Hsp90 [5]. The method of site-specific mutagenesis also revealed conservative $\operatorname{Arg}_{380}$, which is important for ATP-activity of Hsp90 of yeast both in vitro and in vivo. M-domain of Hsp90 is also a factor, responsible for differentiation between different types of client proteins [5].

C-terminal domain. The crystal structure of C-terminal domain of Hsp90 homologue, isolated from E. coli-HtpG, was firstly analyzed (Fig. 2, c) [13]. C-terminal domain is essential for chaperon dimerization. C-domain of HtpG is a dimer, consisting of small $\alpha \beta$-domains. The comparison of primary and secondary structures of C-terminal domains of Hsp90 of prokaryotes and eukaryotes revealed that the most characteristic feature of C-domain of $\mathrm{HtpG}$ is the absence of more than 35 amino acid residues in the terminal segment, namely - in MEEVD-motive, involved in binding with TPR-domain (tetratricopeptide repeat domain) [14]. Nevertheless, the general structure of C-domain of Hsp90 of both eukaryotes and bacteria is very similar and as the crystal structure for eukaryotic Hsp90 is currently absent, the bacterial structure of HtpG may serve as an example of a good working model. Taking the above mentioned into consideration, we may conclude that the complete structure of molecular chaperone Hsp90 is known in general, however only on the basis of its separate domains. There is one more site, the structure of which has not been studied yet. It is the site, located between $\mathrm{N}$ - and M-domains (Fig. 1, a), which is notable for weak conservatism. Both bacterial HtpG and mitochondrial protein do not have this site. Its size is in the range of 30-70 amino acid residues in different types of Hsp90 and isoforms. The experiments in vitro [15] and in vivo [16] proved that this segment is not crucial for Hsp90 functioning.

Conformational changes and ATP-binding. The inhibition of Hsp90 by GA is known to induce its degradation within proteasome. As the chaperone activity of Hsp90 is determined by the balance of ATP and ADP and the presence of protein-assistants [9], there is a question how its ATPase activity influences the interaction with client proteins. This interaction was considered by the authors of [15] to be conformational change in the structure of Hsp90 - the transition from the open form into the closed one. The electron microscopy demonstrated that while interacting with ATP N-terminal domain causes conformational changes in C-domain: the formation of a dimer structure in which monomers are oriented anti-parallelly to each other in the absence of ATP and the formation of a ring structure in the presence of ATP. At the same time the method of X-ray structural analysis of a full-sized HtpG molecule [14] demonstrated the presence of a $\mathrm{V}$-shaped structure, forming dimers, which is notable for parallel location of monomers. The difference in conformations shown by electron microscopy of the crystal structure may reflect considerable flexibility of Hsp90 molecule in the absence of ATP-binding. It is doubtful whether this chaperone molecule has the only fixed conformation. The association of N-terminal domains was demonstrated by several methods for Hsp90 from yeast, chicken, and other eukaryotes. The model of conformational transitions of Hsp90 from the open form into the closed one in the process of ATP binding testifies to the fact that the formation of a dimer is necessary for the hydrolysis of ATP, and two halves of Hsp90 cooperate with each other to achieve dimer conformation, capable of hydrolysing ATP [17]. The stages of achieving this conformation are a complex structural process, in which several areas of Hsp90 are subject to interdependent related transpositions, required for any of two active sites in the dimer to be catalytically active.

These data are in good agreement with the results of kinetic analysis of Hsp90 of humans, which did not reveal the cooperation in classic sense between protomers in Hsp90 dimers at ATP hydrolysis [18]. The notion of "functionally related ATP cycle" is the definition of the process, in which ATP binding stabilizes so called "tense" conformational and functional state of Hsp90, dependent on the presence of $\gamma$-phosphate of ATP, and the subsequent hydrolysis to ADP destabilizes the conformation and allows Hsp90 dimer to relax [5]. The generally accepted model of the ATP-cycle is similar to that of dimers GyrB and MutL, in which N-terminal domains are located very close to each other, and each of them is packed tightly in the direction towards the middle segment of the 
same chain. In ATP-bound state DNA-gyrase B forms so called molecular clamp, which is supposed to close around the DNA chain, and during ATP hydrolysis it releases DNA after its supercoiling $[19,20]$. The peptide binds to the Hsp90 ATP-binding centre in a similar way: it moves inside the chaperone and releases at the moment of ATP hydrolysis [5].

Point mutations in Hsp90, slowing down ATP hydrolysis but not influencing ATP-binding, also decrease the efficiency of ATP-dependent complex [21]. This raises the question: how is the substrate protein kept in the ATP-centre? Although a space encircled by the Hsp90 dimer is probably too small for an entire protein substrate, a sizable domain could be accommodated. There is also assumption that Hsp90 does not enclose its substrate but rather that a substrate-binding face is optimally exposed by Hsp90 in the ATP clamp state.

Recent investigations have proved the obligatory presence of one more nucleotide-binding site at C-terminal domain of Hsp90 [22]. The deletion of 20 amino acid residues in C-terminal domain (660-680) destroys binding of both ATP and novobiocin. C-domain nucleotide-binding site may get activated either when $\mathrm{N}$-terminal site is occupied by a nucleotide or is inactivated, and also when N-site is deleted. On the other hand, the binding of antibiotic novomicin to $\mathrm{C}$-site blocks binding of ATP on N-site as well. Therefore, these two sites, required for ATP binding, work in good coordination, which is important for regulation of Hsp90 conformational state. A role of this additional site is not yet clear, but its inhibition by novoboicin and cis-platinum is interesting for further investigations of its function [22].

Hsp90 functions. Hsp90 functions in vivo as the main component of the majority of multi-protein complexes; along with other factors it is one of the key regulators of numerous signaling pathways, it participates in protein degradation and performs also additional functions of control, rotation, and transfer of various proteins and substrates [5].

Nuclear export. Many signal responses of a cell are the reason of changes in localization of signaling proteins or protein kinases which move and then activate transcription factors, located in the nucleus. There is very little data on the movement of molecules inside the nucleus. Protein mobility inside the nucleus may be diffusely limited, but it might be attributed to a specific fraction of resident nuclear proteins only. As the functions of nuclear proteins are often limited by specific subnucleus compartments, the system of their mobility should be facilitated by a purposeful delivery. Hsp90 regulates the activity of over 100 proteins, involved in the cell signal transduction [23]. These are so called "client" proteins of Hsp90. The cell signal transduction also involves a multi-protein complex Hsp90/Hsp70, forming heterocomplexes of "client" proteins and Hsp90 in the cytoplasm and nucleus.

In case of signaling proteins, acting as transcription factors, the complexes of "client" proteins and Hsp90 also contain one or several TPR-domains of immunophilins or their homologues and bind to TPR-domains on Hsp90. Dynamic assembly of heterocomplexes and Hsp90 is required for fast movement through the cytoplasm to the nucleus along microtubular tracks. In this system the role of immunophilins consists in connecting the "client" protein/Hsp90 complex to the cytoplasmic dynein - a motor protein, providing the movement towards the nucleus. Facilitated diffusion allows the movement of receptor/Hsp90/immunophilin complexes into the nucleus through the nuclear pore complex (NPC). Then non-bound receptors spread in the nucleus, reaching the discrete nuclear centres to bind with chromatin. Active assembly of the heterocomplex with Hsp90 is required for the movement to the nuclear centre and for the active exchange of transcription factors between chromatin and nucleoplasma.

Export of 60S ribosomal subunit. Transition of large substrates through NPC requires significant conformational changes in both NPC and a substrate. Hsp90 supports these structural changes [24].

It was revealed that nuclear export is preferred to nuclear import at the conditions of cellular hypertrophy. In hypertrophied cells, for instance, in cardiomyocytes, the amount of mRNA, delivered to the cytoplasm for protein synthesis, is considerably increased [25], the protein synthesis is enhanced, which should result in the intensified synthesis of ribosomes. It is noteworthy that cardiotrophin-1 (CT-1), which is a factor, promoting the stimulation of cardiomyocyte hypertrophy (it makes the cell grow 
rather than differentiate), stimulates the synthesis of Hsp70 and Hsp90 as well. The enhanced synthesis of Hsp90 in hypertrophied cells seems to allow them to support the free nuclear export of large substrates [26]. The following model is suggested for the nuclear export of $60 \mathrm{~S}$ ribosomal subunits. The transition of 60 S ribosomal subunit through NPC requires the maximal dilation of their pores, facilitated by Hsp90 due to its chaperone function. Then Hsp90 facilitates the transition of $60 \mathrm{~S}$ ribosomal subunit from NPC to cytoskeleton, "leading" the ribosomal subunit through the cell via so called transport cytoskeleton route to its final destination place. It was demonstrated earlier that Hsp90 promotes the formation of ribosomal crystals inside the nucleus [28], and the transition of $60 \mathrm{~S}$ ribosomal subunit through NPC takes place with the mediation of Hsp90. The latter helps the substrate "to dissolve" in the hydrophobic environment of NPC. Taking into consideration a huge size of $60 \mathrm{~S}$ ribosomal subunits, their transport is a more complicated mechanism, involving more factors and various interactions between $60 \mathrm{~S}$ ribosomal subunits and NPC than the same processes for such small substrates as proteins and tRNA.

Hsp90 and signal transduction. Numerous proteins, which are transduction signals in a cell, are main substrates of Hsp90. These proteins depend on Hsp90, which keeps them in active conformation. Disorders in Hsp90 functions due to mutations or treatment with such inhibitors as ansamycins cause numerous changes in the cellular cycle, which correspond to the contribution of Hsp90 into the signaling pathways of the cell. For instance, point mutation in Hsp90 during the regulation of cell division results in the change in many stages of mitotic signaling cascade, the centrosomal cycle in the course of mitosis [28]. In vivo experiments revealed the significance of Hsp90 for the functioning of steroid hormone receptors [29], some tyrosine and serine/threonine kinases, such as pp60/v-src, Wee-1, Cdk4, Raf, and Akt [30] as well as some proteins - synthase of nitrogen oxide and calcineurin [31]. These are large and multi-domain proteins, the functioning of which requires stabilizing relations with other factors, such as ligands for steroid hormone receptors or cyclins for cyclin-dependent kinases. As signaling proteins, having numerous regu- latory functions, are often under the impact of conformational changes, their interaction with Hsp90 may be the result of structural changes in these proteins, which facilitate their recognition by Hsp90.

Hsp90-dependent signaling pathway of steroid hormone receptors is characterized the most [30]. A glucocorticoid receptor monomer (GR) and a progesteron receptor are loaded on Hsp90 via Hsp70/Hor-dependent mechanism, bind to Hsp90 and achieve their hormone-binding conformation. As soon as the folded monomeric receptor is free from the chaperone, it binds to a corresponding steroid hormone immediately, forming a dimer and activating it. A dimer becomes non-stable and is recognized by a chaperone again.

The progesteron receptor and GR are used for the reconstruction of typical multi-chaperone complexes with purified Hsp90, Hsc70, Hop, and p23 of mammals [32]. Hsp90/Hop/Hsp70/Hsp40 complex was called a foldosome. A foldosome converts GR from the folded state, in which a steroid-binding site is closed and thus is not capable of interacting with the steroid, into the open state, accessible for the steroid [33]. While forming a foldosome Hop binds to Hsp90 and Hsp70 via TPR-domains. Hop binds a dimer Hsp90 molecule, and chaperone Hsp40 is a co-chaperone of Hsp70, which is also present in the tetracomplex and executes $\mathrm{ATP} / \mathrm{Mg}^{2+}$ - and $\mathrm{K}^{+}$-dependent opening of steroid-binding site. While the steroid-binding site is open, Hsp90 converts into ATP-bound conformation, dynamically stabilized by p23 protein, which results in releasing Hop from Hsp90. The complex formed is assembled in such a way that several changes in it are occurring in dynamic fashion. Immunophilins are also connected to Hsp90 via TPR-domains, and when Hop leaves the complex, the immunophilin may bind a single TPR-acceptor site on the receptor-binding Hsp90 dimer. Some Hsp70 proteins may also form an intermediate complex.

Although the function of Hsp90, determined by ATP hydrolysis in the course of steroid hormone receptor maturation, was demonstrated, it is doubtful in case of in vitro conditions. There is an assumption regarding V-src and other kinases that Hsp90 stabilizes unprotected catalytic domains prior to assembling the 
kinase into the final signaling complex. This mechanism is conceptually related to the steroid receptor pathway. The variant of the signaling pathway of ecdysone steroid receptor (EcR - receptor of family of heterodimeric retinoid $\mathrm{X}$ ) was described for Drosophila. Along with the protein partner USP, the isolated receptor is ready to bind to EcR rather than to DNA, and Hsp90 converts a hormone-bound receptor into the active DNA-binding state [34].

There is one more mechanism of interaction, which allows human Hsp90 regulate its own expression by means of isolation of monomeric inactive form of HSF1 (heat shock transcription factor) at non-stress conditions [35], when disorderly placed proteins, formed as a result of stressful condition, may compete with HSF1 for binding to Hsp90, thus releasing the transcription factor for trimerization and initiation of heat shock response.

GR is an exellent model for the study on nucleus-cytoplasmic transfer of the transcription factor from the cytoplasm to the nucleus, as it is usually located in the cytoplasm of cells, free from the hormone, and its fast transition to the nucleus is hormone-dependent. It was revealed that GRs were constantly moving between the cytoplasm and the nucleus, thus they support nucleus accumulation of GR/Hsp90 complex via ligand-dependent transformation [36]. The transition of GR takes place along with Hsp90 movement. The transformation, dependent on the ligand, converts the receptor from the state of forming a "stable" complex with Hsp90 into the state when GR/Hsp90 complex is more active in the cycle of its accumulation and dissimilation. A more active complex is required for fast movement of the receptor. The model of retrograde transition of GR with the help of dynein along cytoskeleton tracks was first suggested in 1993 [37]. Recent years have witnessed a considerable improvement of this model. As of date, it is known that some Hsp90-bound immunophilins are bound by peptidyl-prolyl-isomerase (PPIase) domains with the cytosplasmatic dynein. The complex was isolated from the cells and reconstructed in a cell-free system [38]. The transition of GR and several other transcription factors from the cytoplasm into the nucleus is either slowed down or blocked by Hsp90 inhibitors, co-expression of the fragment of
PPIase-domain, blocking the binding of immunophilin to dynein and co-expression of dynamitin, which causes the dissociation of dynein and its "load". Therefore, the obvious proofs were obtained in vivo to support the model of GR transition.

Contrary to the penetration of proteins into mitochondria and other organelles, where proteins should be unfolded to pass, their transition through NPC does not influence the native state due to a considerable size of pores enough for rather large multimeric complexes $-(1-3) \cdot 10^{6} \mathrm{Da}[38]$. As soon as signaling proteins approach the nucleus membrane, they get into the pores via facilitated diffusion. Currently the preference is given to the model of receptor/Hsp90/immunophilin complex for transfer through nuclear pores [39]. In fact neither Hsp90 nor Hsp90-bound immunophilins have their own nuclear localization signals (NLS). They are present in the nucleus due to their attendant transfer via numerous NLS-containing "client" proteins.

The interaction of nuclear proteins with soluble partners or the ones in aggregate state results in a considerable impairment of their mobility [40]. Specific nuclear compartments often govern the functions of nuclear proteins. In particular, the authors of $[41,42]$ demonstrated the transition of proteins from the nucleus along the tracks through the pores, but the nature of threads (who plays a role of nuclear actin?) and potential moving motor proteins (a role of nuclear myo$\sin$ ?) is yet to be discovered. The ovary cells of Chinese hamster were used to demonstrate that expressed nuclear GR FKBP52 and hormone-free GR are located in the same loci of the nucleus. Similar localization is in good agreement with the assumption that FKBP52 moves to the target along the suggested "staging areas" inside the nucleus at least.

There are evidences to the fact that GR/Hsp90 complex is necessary for the hormone fixation, that is also proven by the ability of the receptor to recycle in the GR/Hsp90 complex inside the nucleus. The same cycle in the nucleus was demonstrated in DeFranko laboratory [43]. It was revealed that GR, released from chromatin, may repeatedly be used $n$ in the process of binding the hormone without exit out of the nucleus. Geldanamycin inhibits repeated use of the hormone and thus inhibits the release of GR from 
chromatin. It is in agreement with the role of Hsp90/Hsp70 complex in the termination of transcription activity in case of decrease in the level of the free hormone. In situ system was used to demonstrate the displacement of the receptor within the nucleus on the model of purified Hsp90/Hsp70 complex. After the dissociation of the hormone $[\mathrm{H}] \mathrm{GRs}$ are released from binding sites on chromatin. However, there is still a question on the time of transformation of GR dimer into a monomer: does it happen while the receptor is bound to chromatin or when it makes a complex with Hsp90? The stehiometry of the final heterocomplex is one GR molecule, bound to Hsp90 dimer [44]. Hop co-chaperone organizes all the chaperones, participating in this process, into one complex - Hsp90/Hop/Hsp70/Hsp40. When ATP-binding centre of GR/Hsp90 complex is in active conformation, GR returns to its binding state, and p23 interacts with Hsp90 to stabilize the complex. Nuclear GR, used repeatedly in GR-Hsp90-p23 complex, may interact with the hormone not leaving the nucleus and then participate in binding again.

p23 component is of important instrument in the investigation on the role of Hsp90 in the course of transcription complex disassembly and in the study on repeated binding of the receptor in the nucleus. In vitro experiments demonstrated two mechanisms of p23 action [24]. The experiments on GR/Hsp90 assembly demonstrated that p23 acts as co-chaperone Hsp90 and interacts with GR/Hsp90 complex as soon as it is formed, thus stabilizing it. p23 may also act as a chaperone, inhibiting the aggregation of denaturated proteins and keeping them in folded state. In vivo experiments showed the participation of p23 in the stabilization of chaperone complex Hsp90/Hsp70 [44]. There are also numerous evidences to the fact that as a part of heterocomplex Hsp90 is involved in the process of transition of transcriptional factors, which are "client" proteins of Hsp90, along the cytoplasm and nucleus.

Hsp90 and protein degradation. A visit card of the activity of ansamycin in living cells is the induction of degradation of substrate proteins by Hsp90 chaperone using ubiquitin-proteasome pathway. Though historically ansamycins were discovered as inhibitors of tyrosine kinases, they are currently known as inhibitors of Hsp90. Ansamycins are capa- ble of inhibiting chaperone-mediated folding of Hsp90 substrates, thus blocking their disassembly from Hsp90. On the other hand, some substrate proteins are released by ansamycin from the complex with Hsp90 [45,46].

In what way do Hsp90-bound peptides serve as a degradation target? TPR co-chaperone CHIP, capable of recognizing both chaperones (hsp90 and Hsc70), contains a so called U-domain, which is homologous to E4-ubiquitin factors, and may present chaperone-bound non-placed proteins for ubiquitination. Therefore, super-expression of CHIP in cultivated cells results in the increase in ubiquitination and degradation of GR and transmembrane regulator of mucoviscidosis of CFTR, which are the substrates of Hsp90 and Hsc70. CHIP activity is required for the kinetics of protein folding and degradation. Due to this activity the substrates interact with Hsp90 longer, for instance as a result of inhibiting ATP-centre for their further ubiquitination. The existence of CHIP allows the assumption that similarly to protein folding the degradation of proteins is regulated by additional factors [45].

Recent studies demonstrated [47] that Hsp90 is bound directly to ribosomal protein S3 (rpS3). Due to the formation of Hsp90/rpS3 complex the ribosomal protein $\mathrm{rpS} 3$ is protected from ubiquitination and proteasome degradation, which allows it to keep its function in biogenesis of the ribosome later. Hsp90 inhibitors influence the disassembly of $\mathrm{rpS} 3$ from Hsp90, further association of the protein and Hsp70 and the induction of its degradation. It was also revealed that the ribosomal protein S6 (rpS6) interacts with Hsp90 as well, and chaperone inhibitors have similar influence on its disassembly from Hsp90 and further degradation. Therefore, there are grounds for the assumption that Hsp90 regulates the function of ribosomes via supporting the stability of $40 \mathrm{~S}$ ribosomal proteins, for instance of $\mathrm{rpS} 3$ and $\mathrm{rpS} 6$.

\section{Cardioprotection and pharmacological prop-} erty of Hsp90. The experiments on the culture of cardiomyocytes demonstrated that Hsp90 stabilizes the protein ErbB2 $[48,49]$ which is a vital component of GPCR-signaling pathway of cardiomyocytes. The experiments on mice, performed to investigate the influence of doxorubicin, the inhibitor of cancer cells, 
demonstrated that Hsp90 is responsible for the stabilization of ErbB2 in the heart. The increase in the quantity of ErbB2 in the heart in response to some damage may be an impulse to the survival of cells. However, the damage exceeding the threshold level (high concentrations of doxorubicin) cannot be prevented by the activation of ErbB2 or Akt. It is noteworthy that the increase in the concentration of ErbB2 (along with further activation of GRCR-signals) takes place prior to obvious impairments of systolic function of the heart. Such change in ErbB2 content may be used in the diagnostics of patients, who receive the treatment with anti-ErbB2 in the case of breast cancer, and who have a risk of developing heart symptoms. Doxorubicin is the inhibitor, enhancing the disassembly of ErbB2 and Hsp90, which results in the degradation of ErbB2 protein. The treatment of cancer of suckling gland leads to the increased level of the expression of Hsp90 and Hsp70 in the heart. Oxidative damage of the myocardium, induced by the stress, influences the expression of Hsp90 in vivo. Besides doxorubicin, cyclosporin A [50] also induces in vivo expression of Hsp90 in the heart, which is related to the modulation of endothelial NO-synthase signaling pathway. It is evident that the search for novel anticancer treatment should include the estimation of their possible side effects in vivo, namely, their influence on the level of Hsp90 in the cell, in particular, in cardiomyocytes.

The superexpression of Hsp90 in the ischemic stage of cardiac infarction may protect the cardiac muscle from ischemia-reperfusion dilation due to the stimulation of the NO endothelial pathway [51]. The culture of endothelial cells was used to demonstrate the association of cardio-protective activity of Hsp90 and its ability to interact with the kinase Akt and calcineurin-phosphatase as an adapter, promoting both phosphorilation of $\mathrm{Ser}_{1177}$ and de-phosphorilation of $\mathrm{Thr}_{495}$ eNOS-synthase (endothelial nitric oxide synthase). Hsp90 is a promising target for increasing the formation of eNOS in vivo, which may be efficient in respect of decreasing the level of myocardial/reperfusion injury.

A role of Hsp90 in the regulation of apoptosis is rather ambiguous and depends on apoptotic stimuli, usually exposing anti-apoptotic activity. The forma- tion of Akt-Hsp90 complex in vivo stabilizes the activity of Akt kinase and protects the cells from apoptosis, preventing the dephosphorylation of Akt [30]. Kinases Raf-1 and MEK participate in such important cellular processes as proliferation, differentiation, and apoptosis, and are vital participants of pathogenesis of cardiohypertrophy and cardiac deficiency [52]. Hsp90 was found in the association with many components and regulators of the Raf-1/MEK signaling in Hsp90 molecule of Drosophila suppress the activity of Raf- 1 and decrease the affinity between Hsp90 and Raf-1. Geldanamycin also inhibits the formation of Raf-1/Hsp90 complex and causes the degradation of Raf-1. The activation of Raf-1 kinase prevents the apoptosis of cardiomyocytes [52]. Hsp90 alone or in the complex with Hsp70 binds Apaf-1 and prevents the formation of Apaf-1 complex with cytochrome $\mathrm{C}$, thus being a negative regulator of CytC-mediated apoptosis. Taking the abovementioned into consideration, one may assume that Hsp90 takes an active part in preventing the apoptosis of cardiomyocytes.

The process of formation of new myofibrils occurs during the entire period of organism development. It is well known that cardiomyocytes do not divide, but they are capable of responding to increasing hemodynamic load, enlarging the weight and capacity of the contractile apparatus. Such hypertrophy of the heart may occur both in normal conditions (for instance, in sportsmen with high physical strain) and at heart diseases of different etiology. In the most complicated forms the growth of heart tissue results in the decrease in the size of its chambers, decrease in the volume of pumped out blood and is dangerous for the life of a patient [54].

It is known that Hsp90 and Hsc70 are bound by myosin, forming a multimeric complex of myosin threads. The half-life of this complex is short. It is accumulated in case of inhibiting Hsp90 with geldanymicin or due to other reasons, postponing the assembly of myofibrils. The cardiomyocyte seems to launch the same mechanism of hypertrophy as in the case of embryonic period when the synthesis of myofibrils takes place depending on regulatory proteins. The inhibitions of biosynthesis of these regulatory components stops the assembly of myofibrils. 
As it was already mentioned above, the activity of Hsp90 (similar to other chaperones) is regulated and modulated via the interaction with adaptor proteins and co-chaperones, for instance, p23 or recently discovered Sgt1 [55] and melusin [56, 57]. It was found out that Sgt1 is present in various cells and tissues of mammals, including the skeletal and muscle parts, and melusin is synthesized only in the skeletal and heart tissues. The interaction of Sgt1 and Hsp90/Hsp70 is modulated by S100A6 protein via $\mathrm{Ca}^{2+}$-dependent pathway, which may be a significant moment in the development of apoptosis, depending on intracellular concentration of calcium.

Recent studies have shown that melusin is a new component - co-chaperone of Hsp90, capable of protecting the citrate synthase (CS) from aggregation, possibly due to heat shock [58]. It is also noteworthy that inhibitors of Hsp90 are inductors of chaperons synthesis, in particular, of Hsp90 itself. The synthesis of chaperones in the cell is induced by HSF-1. Hsp90 dissociates from HSF-1 at the moment of its activation due to competing binding of unfolded proteins [59]. The inhibitors of Hsp90 promote the transcription activity of HSF-1 due to the destruction of Hsp/HSF-1 complex, as a result HSF-1 releases and translocates into the nucleus, phosphorylates and binds to HSE, thus inducing the transcription of genes $h s p 40, h s p 70$, and $h s p 90$. In particular, due to binding of Hsp90 the inhibitor radicicol activates the transcription of genes of chaperones in the cells of neonatal cardiomyocytes of rats.

Therefore, Hsp90 modulates the level of cardioprotection of cardiomyocytes, thus regulating the expression of Hsp90 directly via its ability to bind HSF-1 [60]. In cardiomyocytes the expression of Hsp90 and cardioprotection are modulated by the amount of Hsp90. The application of non-toxic derivatives of radicicol may become one of the stages of developing therapeutic means for the treatment of cardiovascular diseases.

The introduction of the gene hsp90 into the myocardium [51] prevents ischemic cardiomyopathy in pigs and stimulates the synthesis of eNOS by chaperone Hsp90. It is well-known that NO has a cardio-protective function, but at the same time the increase in the level of its synthesis results in appear- ance of cytotoxic peroxynitrites with superoxide radicals, which damage tissues. Prolonged production of NO, determined by the accumulation of tumour growth suppressor p53, results in apoptosis.

Regardless of the fact that superoxide anion also induces apoptosis, the balance of NO and superoxide anion results in cross-protective effect and the process of apoptosis is considerably inhibited [61]. The investigation of the functions of molecular chaperone Hsp90, one of which is cardioprotection, and the estimation of possible role of inhibitors of Hsp90 in this function, makes this protein a promising tool of cardio-vascular therapy.

\section{I. В. Крупська}

Молекулярний шаперон Нsp90: структура, функції та участь у кардіоваскулярній патології

Резюме

Огляд присвячено аналізу структурних і функціональних властивостей молекулярного шаперону Hsp90. Hsp90 є представником широко розповсюдженої родини білків теплового шоку. Його знайдено в бактеріях та в еукаріотах, але він відсутній в архебактеріях, є одним із ключових регуляторів багаточисельних сигнальних шляхів, які обумовлюють ріст і розвиток клітин, апоптоз, індукцію автоімунних процесів і прогресію сериевої недостатності. Повна функціональна активність ицього білка виявляється у комплексі з іншими молекулярними шаперонами та кошаперонами. Молекулярні взаємодї між шаперонами, різноманітними сигнальними білками $і$ білками-партнерами критичні для нормального функиіонування сигнальних шляхів, а їхне порушення призводить до змін у фізіології клітини і навіть до ї̈ загибелі.

Ключові слова: Нsp90, домен, кристалічна структура, сигнальний шлях, апоптоз.

\section{И. В. Крупская}

Молекулярный шаперон Нsp90: структура, функции и участие в кардиоваскулярной патологии

Резюме

Обзор посвящен анализу структурных и функииональных свойств молекулярного шаперона Нsp90. Нsp90 является представителем широко распространенного семейства белков теплового шока. Он обнаружен в бактериях и в эукариотах, но отсутствует в архебактериях, служит также одним из клю- 
чевых регуляторов многочисленных сигнальних путей, определяющих рост и развитие клеток, апоптоз, индукиию аутоиммунных реакций и прогрессию сердечной недостаточности. Полная функциональная активность этого белка проявляется в комплексе с другими молекулярними шаперонами и кошаперонами. Молекулярные взаимодействия между шаперонами, различными сигнальными белками и белками-партнерами критичны для нормального функционирования сигнальных путей, а нарушение их вызывает изменения в физиологии клетки вплоть до ее гибели.

Ключевые слова: Нsp90, домен, кристаллическая структура, сигнальный путь, апоптоз.

\section{REFERENCES}

1. Seckler R., Jaenicke R. Protein folding and protein refolding // The FASEB J.-1992.-6.-P. 2545-2552.

2. Ellis J. Proteins as molecular chaperones // Nature.-1987.328, N 6129.-P. 378-379.

3. Versteeg S., Mogk A., Schumann W. The Bacillus subtilis $h t p G$ gene is not involved in thermal stress management // Mol. Gen. Genet.-1999.- 261, N 4.-P. 582-588.

4. Prodromou C., Piper P. W., Pearl L. H. Expression and crystallisation of the yeast Hsp82 chaperone and preliminary Xray diffraction studies of the amino-terminal domain // Proteins: Structure, Function, Genetics.-1996.-25, N 4.-P. 517522.

5. Pearl L. H., Prodromou C. Structure and mechanism of the Hsp90 molecular chaperone machinery // Annu. Rev. Biochem.-2006.-75.-P. 271-294.

6. Obermann W. M. J., Sondermann H., Russo A. A., Pavletich N. P., Hartl F. U. In vivo function of Hsp90 is dependent on ATP binding and ATP hydrolysis // J. Cell Biol.-1998.-143, N 4.-P. 901-910.

7. Prodromou C., Roe S. M., Piper P. W., Pearl L. H. A molecular clamp in the crystal structure of the $\mathrm{N}$-terminal domain of the yeast Hsp90 chaperone // Nat. Struct. Biol.-1997.-4, N 2.-P. 477-482.

8. Chavany C., Mimnaugh E., Miller P., Bitton R., Nguyen P. p185erbB2 binds to GRP94 in vivo // J. Biol. Chem.-1996.271, N 9.-P. 4974-4977.

9. Prodromou C., Roe S. M., O'Brien R., Ladbury J. E., Piper P. $W$., Pearl L. H. Identification and structural characterization of the ATP/ADP-binding site in the Hsp90 molecular chaperone // Cell.-1997.-90, N 1.-P. 65-75.

10. Soldano K. L., Jivan A., Nicchitta C. V., Gewirth D. T. Structure of the N-terminal domain of GRP94 // J. Biol. Chem.2003.-278, N 48.-P. 48330-48338.

11.Huai Q., Wang H. C., Liu Y. D., Kim H. Y., Toft D., Ke H. M. Structures of the N-terminal and middle domains of $E$. coli Hsp90 and conformation changes upon ADP binding // Structure.-2005.-13, N 6.-P. 579-590.
12.Meyer P., Prodromou C., Hu B., Vaughan C., Roe S. M., Panaretou B., Piper P. W., Pearl L. H. Structural and functional analysis of the middle segment of hsp90: implications for ATP hydrolysis and client protein and cochaperone interactions // Mol. Cell.-2003.-11, N 3.-P. 647-658.

13. Minami Y., Kimura Y., Kawasaki H., Suzuki K., Yahara I. The carboxy-terminal region of mammalian HSP90 is required for its dimerization and function in vivo // Mol. Cell. Biol.1994.-14, N 2.-P. 1459-1464.

14. Harris S. F., Shiau A. K., Agard D. A. The crystal structure of the carboxy-terminal dimerization domain of htpG, the Escherichia coli Hsp90, reveals a potential substrate binding site // Structure.-2004.-12, N 6.-P. 1087-1097.

15. Prodromou C., Panaretou B., Chohan S., Siligardi G., O'Brien R., Ladbury J. E., Roe S. M., Piper P. W., Pearl L. H. The ATPase cycle of Hsp90 drives a molecular «clamp» via transient dimerization of the $\mathrm{N}$-terminal domains // The EMBO J.-2000.-19, N 16.-P. 4383-4392.

16. Louvion J. F., Warth R., Picard D. Two eukaryote-specific regions of $\mathrm{Hsp} 82$ are dispensable for its viability and signal transduction functions in yeast // Proc. Nat. Acad. Sci. USA.1996.-93, N 24.-P. 13937-13942.

17. Siligardi G., Hu B., Panaretou B., Piper P. W., Pearl L. H., Prodromou $C$. Co-chaperone regulation of conformational switching in the Hsp90 ATPase cycle // J. Biol. Chem.2004.-279, N 50.-P. 51989-51998.

18. McLaughlin S. H., Ventouras L. A., Lobbezoo B., Jackson S. $E$. Independent ATPase activity of Hsp90 subunits creates a flexible assembly platform // J. Mol. Biol.-2004.-344, N 3.P. 813-826.

19. Berger J. M., Gamblin S. J., Harrison S. C., Wang J. C. Structure and mechanism of DNA topoisomerase II // Nature.1996.-379, N 6562.-P. 225-232.

20. Ban C., Junop M., Yang $W$. Transformation of MutL by ATP binding and hydrolysis: a switch in DNA mismatch repair // Cell.-1999.-97, N 1.-P. 85-97.

21. Young J. C., Hartl F. U. Polypeptide release by Hsp90 involves ATP hydrolysis and is enhanced by the co-chaperone p23 // The EMBO J.-2000.-19, N 17.- P. 5930-5940.

22. Soti C., Racz A., Csermely P. A nucleotide-dependent molecular switch controls ATP binding at the $\mathrm{C}$-terminal domain of hsp90: N-terminal nucleotide binding unmasks a C-terminal binding pocket // J. Biol. Chem.-2002.-277, N 9.P. 7066-7075.

23. Pratt W. B., Galigniana M. D., Harrell J. M., DeFranco D. B. Role of hsp90 and the hsp90-binding immunophilins in signalling protein movement // Cell. Signal.-2004.-16, N 8.P. 857-872.

24. Perez-Terzic C., Gacy M. A., Bortolon R. Directed inhibition of nuclear import in cellular hypertrophy // J. Biol. Chem.2001.-276, N 23.- P. 20566-20571.

25. Swynghedauw B. Molecular mechanisms of myocardial remodeling // Physiol. Rev.-1999.-79, N 1.-P. 215-262.

26. Schlatter H., Langer T., Rosmus S., Onneken M.-L., Fasold $H$. A novel function for the $90 \mathrm{kDa}$ heat-shock protein (Hsp90): facilitating nuclear export of 60S ribosomal subunits // Biochem. J.-2002.-362, N 3.-P. 675-684.

27. Vittone M. B. A., Maraldi N. M. Cell stress and ribosome crystallization // J. Submicrosc. Cytol. Pathol.-1995.-27, N 2.P. 199-207. 
28. Helmbrecht K., Zeise E., Rensing L. Chaperones in cell cycle regulation and mitogenic signal transduction: a review // Cell Prolif.-2000.-33, N 6.-P. 341-365.

29. Sato S., Fujita N., Tsuruo T. Modulation of Akt kinase activity by binding to Hsp90 // Proc. Nat. Acad. Sci. USA.-2000.97, N 20.-P. 10832-10837.

30. Young J. C., Moarefi I., Hartl F. U. Hsp90: a specialized but essential protein-folding tool // J. Cell Biol.-2001.-154, N 2.-P. 267-274.

31. Imai J., Yahara I. Role of Hsp90 in salt stress tolerance via stabilization and regulation of calcineurin // Mol. Cell. Biol.2000.-20, N 24.-P. 9262-9270.

32. Dittmar K. D., Banach M., Galigniana M. D., Pratt W. B. The role of DnaJ-like proteins in glucocorticoid receptor-hsp90 heterocomplex assembly by the reconstituted hsp90-p60hsp70 foldosome complex // J. Biol. Chem.-1998.-273, N 13.-P. 7358-7366.

33. Pratt $W$. B., Toft D. O. Regulation of signaling protein function and trafficking by the hsp90/hsp70-based chaperone machinery // Exp. Biol. and Med.-2003.-228.-P. 111-133.

34. Arbeitman M. N., Hogness D. S. Molecular chaperones activate the Drosophila ecdysone receptor, an RXR heterodimer // Cell.-2000.-101, N 1.-P. 67-77.

35. Zou J., Guo Y., Guettouche T., Smith D., Voellmy R. Repression of heat shock transcription factor HSF1 activation by HSP90 (HSP90 complex) that forms a stress-sensitive complex with HSF1 // Cell.-1998.-94, N 4.- P. 471-480.

36. DeFranco D. B., Madan A. P., Tang Y., Chandran U. R., Xiao $N$., Yang $J$. Nucleocytoplasmic shuttling of steroid receptors // Vitam. Horm.-1995.- 51.-P. 315-338.

37. Davies T. H., Ning Y. M., Sanchez E. R. A new first step in activation of steroid receptors: hormone-induced switching of FKBP51 and FKBP52 immunophilins // J. Biol. Chem.2002.-277, N 7.- P. 4597-4600.

38. Gorlich D., Kutay U. Transport between the cell nucleus and the cytoplasm // Annu. Rev. Cell Biol.-1999.-15.-P. 607660.

39. Hache R. J. G., Tse R., Reich T., Savory G. A., Lefebvre Y. A. Nucleocytoplasmic trafficking of steroid-free glucocorticoid receptor // J. Biol. Chem.-1999.-274, N 3.-P. 1432-1439.

40. Phair R. D., Misteli T. High mobility of proteins in the mammalian cell nucleus // Nature.-2000.-404, N 3.-P. 604-609.

41. Meier U. T., Blobel G. Nopp140 shuttles on tracks between nucleolus and cytoplasm // Cell.-1992.-70, N 1.-P. 127-138.

42. Czar M. J., Owens-Grillo J. K., Yem A. W. The hsp56 immunophilin component of untransformed steroid receptor comp- lexes is localized both to microtubules in the cytoplasm and to the same nonrandom regions within the nucleus as the steroid receptor // Mol. Endocrinol.-1994.-8, N 12.-P. 1731-1741.

43. DeFranco D. B. Navigating steroid hormone receptors through the nuclear compartment // Mol. Endocrinol.-2002.-16, N 7.-P. 1449-1455.

44. Morishima Y., Kanelakis K. C., Murphy P. J. M., Lowe E. R., Jenkins G. J., Osawa Y., Sunahara R. K., Pratt W. B. The Hsp90 cochaperone p23 is the limiting component of the multiprotein Hsp90/Hsp70-based chaperone system in vivo where it acts to stabilize the client protein/Hsp90 complex // J. Biol. Chem.-2003.-278, N 49.-P. 48754- 48763.
45. Meacham G. C., Patterson C., Zhang W., Younger J. M., Cyr $D$. $M$. The Hsc 70 co-chaperone CHIP targets immature CFTR for proteasomal degradation // Cell Biol.-2001.-3.-P. 100105.

46. Hohfeld J., Cyr D. M., Patterson C. From the cradle to the grave: molecular chaperones that may choose between folding and degradation // EMBO Rep.-2001.-2, N 10.-P. 885890.

47. Kim T-S., Jang C-Y., Kim H. D., Lee J. Y., Ahn B-Y., Kim J. Interaction of Hsp90 with ribosomal proteins protects from ubiquitination and proteasome-dependent degradation // Mol. Biol. Cell.-2006.-17, N 2.-P. 824-833.

48. Zaarur N., Gabai V. L., Porco J. A., Calderwood S., Sherman $M$. $Y$. Targeting heat shock response to sensitize cancer cells to proteasome and Hsp90 inhibitors // Cancer Res.-2006.66, N 31.-P. 783-791.

49. Gabrielson K., Bedja D., Pin S., Tsao A., Gama L., Yuan B., Muratore $N$. Heat shock protein 90 and Erbb2 in the cardiac response to doxorubicin injury // Cancer Res.-2007.- 67, N 4.-P. 1436-1441.

50. Rezzani R., Rodella L., Dessy C., Daneau G., Bianchi R., Feron $O$. Changes in HSP90 expression determine the effects of cyclosporine A on the NO pathway in rat myocardium // FEBS Lett.-2003.-552, N 2-3.-P. 125-129.

51. Kupatt C., Dessy C., Hinkel R., Raake P., Daneau G., Bouzin $C$., Boekstegers P., Feron O. Heat shock protein 90 transfection reduces ischemia-reperfusion-induced myocardial dysfunction via reciprocal endothelial NO synthase Serine 1177 phosphorylation and Threonine 495 dephosphorylation // Arterioscler. Thromb. Vasc. Biol.-2004.-24, N 8.P. 1435-1441.

52. Yamaguchi O., Watanabe T., Nishida K., Kashiwase K., Higuchi Y., Takeda T., Hikoso S., Hirotani S., Asahi M., Otsu K. Cardiac-specific disruption of the $c-r a f-1$ gene induces cardiac dysfunction and apoptosis // J. Clin. Invest.- 2004.-114, N 7.-P. 937-943

53. Nollen E. A. A., Morimoto R. I. Chaperoning signaling pathways: molecular chaperones as stress-sensing «heat shock» proteins // J. Cell Sci.-2002.-115, N 14.-P. 2809-2816.

54. Srikakulam R., Winkelmann D. A. Chaperone-mediated folding and assembly of myosin in striated muscle // J. Cell Sci.-2004.-117, N 4.-P. 641-652.

55. Nowotny M., Spiechowicz M., Jastrzebska B., Filipek A., Kitagawa K., Kuznicki J. Calcium-regulated interaction of Sgt1 with S100A6 (Calcyclin) and other S100 proteins // J. Biol. Chem.-2003.-278, N 29.-P. 26923-26928

56. Brancaccio M., Guazzone S., Menini N., Sibona E., Hirsch E., De Andrea M., Rocchi M., Altruda F., Tarone G., Silengo $L$. Melusin is a new muscle specific interactor for beta(1) integrin cytoplasmic domain // J. Biol. Chem.-1999.-274, N 41.-P. 29282-29288.

57. Michowski W., Lee Y-T., Chazin W. J., Kuznicki J. Melusin binds calcyclin (S100A6) protein in a $\mathrm{Ca}^{2+}$-dependent fashion // Eur. J. Biochem.-2003.-1 Suppl., 1 July: Abstr. N P3.7-09.

58. Sbroggib M., Ferretti R., Percivalle E., Gutkowska M., Zylicz A., Michowski W., Kuznicki J., Accornero F., Pacchioni B., Lanfranchi G., Hamm J., Turco E., Silengo L., Tarone G., Brancaccio $M$. The mammalian CHORD-containing protein melusin is a stress response protein interacting with Hsp90 and Sgt1 // FEBS Lett.-2008.-582, N 13.-P. 1788-1794. 
59. Morimoto R. I. Dynamic remodeling of transcription complexes by molecular chaperones // Cell.-2002.-110, N 3.P. 281-284

60. Griffin T. M., Valdez T. V., Mestril R. Radicicol activates heat shock protein expression and cardioprotection in neonatal rat cardiomyocytes // Amer. J. Physiol. Heart Circ. Physiol.2004.-287, N 3.-P. 1081-1088.
61. Ferdinandy P., Schulz R. Nitric oxide, superoxide, and peroxynitrite in myocardial ischaemia-reperfusion injury and preconditioning // Brit. J. Pharmacol.-2003.-138, N 4.P. 532-543.

UDC 577.21

Received 27.11.08 